Article

\title{
Extent and Severity of Caliciopsis Canker in New England, USA: An Emerging Disease of Eastern White Pine (Pinus strobus L.)
}

\section{Isabel A. Munck ${ }^{1, *}$, William Livingston ${ }^{2}$, Kyle Lombard ${ }^{3}$, Thomas Luther ${ }^{1}$, William D. Ostrofsky ${ }^{4}$, Jennifer Weimer ${ }^{3}$, Stephen Wyka ${ }^{5}$ and Kirk Broders ${ }^{5}$}

1 NA State \& Private Forestry, USDA Forest Service, 271 Mast Road, Durham, NH 03824, USA; E-Mail: tluther@fs.fed.us

2 School of Forest Resources, the University of Maine, Orono, ME 04469, USA; E-Mail: WilliamL@maine.edu

3 New Hampshire Department of Resources and Economic Development, New Hampshire Division of Forests and Lands, 172 Pembroke Road, Concord, NH 03302, USA;

E-Mails: kyle.lombard@dred.state.nh.us (K.L.); Jennifer.Weimer@dred.nh.gov (J.W.)

4 Maine Forest Service, Maine Department of Agriculture, Conservation and Forestry, 22 State House Station, Augusta, ME 04333, USA; E-Mail: bill.ostrofsky@maine.gov

5 Department of Biological Sciences, University of New Hampshire, 105 Main Street, Durham, NH 03824, USA; E-Mail: kirk.broders@unh.edu (S.W.); stephenwyka@gmail.com (K.B.)

* Author to whom correspondence should be addressed; E-Mail: imunck@fs.fed.us; Tel.: +1-603-868-7636; Fax: +1-603-868-1066.

Academic Editors: Jan Stenlid, Jonas Oliva and Audrius Menkis

Received: 6 October 2015 / Accepted: 19 November 2015 / Published: 24 November 2015

Abstract: Caliciopsis canker is an emerging problem in Pinus growing regions of Eastern North America. The fungal disease caused by Caliciopsis pinea is associated with overstocked stands and poor sites, but few quantitative data are available. The objective of this study, therefore, was to assess the extent and severity of Caliciopsis canker and to explore environmental variables associated with disease to identify areas at risk of damage. During 2014, 58 sites across New England with $>75 \%$ P. strobus basal area in public lands were surveyed. Most sites (72\%) had Caliciopsis canker signs or symptoms. Caliciopsis pinea was successfully identified with molecular techniques. In sites with Caliciopsis canker, $36 \%$ of the mature pines were symptomatic. Pole sized and suppressed trees were more likely to be damaged than larger trees with dominant crown positions 
$(p<0.05)$. Pinus strobus density for sites with Caliciopsis canker was 311 trees/ha (mean $P$. strobus stand diameter $=40 \mathrm{~cm}$ ) compared to 220 trees $/$ ha (mean white pine stand diameter $=43 \mathrm{~cm})$ for sites without Caliciopsis canker $(p=0.1)$. Caliciopsis canker symptoms tended to appear more frequently in stands with excessively drained, coarse textured soils derived from glacial outwash $(86 \%)$ or stands with poorly drained soils and low fertility $(78 \%)$ than in stands with well drained, more fertile soils $(59 \%)(p=0.1)$. The severity of symptoms varied among soil groups and was greater for excessively drained, nutrient poor soils than for well-drained, more fertile soils $(p=0.027)$.

Keywords: Caliciopsis pinea; pine canker; pine pathogen; fungus; forest disease

\section{Introduction}

The pathogenic fungus, Caliciopsis pinea Peck that causes Caliciopsis canker, has been found infecting native and exotic pines in Eastern North America and in Europe. In Eastern USA, C. pinea has been reported on native Pinus L.: P. strobus, P. echinata Mill, P. pungens Lamb, P. rigida Mill, $P$. virginiana Mill, and $P$. taeda L. [1]. In Europe, $C$. pinea has been observed on exotic Pinus: P. echinata, P. pungens, P. rigida, P. virginiana, and P. radiata D. Don [1]. Caliciopsis canker has also been described in native European Pinus: P. pinaster Aiton, P. pinea L., and P. halepensis Mill [2]. Other species within the genus Caliciopsis infect conifers in Western North America [3]. Trees of all age classes are affected and saplings are sometimes killed. External symptoms include profuse pitching and cankers in the main stem and branches (Figure 1a,b). Ascocarps are stalked, look like black spines 1-3 mm long and can be observed at the surface of roughed bark at the axils of branches (Figure 1c) [4]. Caliciopsis pinea has been referred to as a weak pathogen of $P$. pinaster in France [5]. The pathogen, however, can cause extensive damage to P. strobus (eastern white pine) in Northeastern USA where saplings are killed and the wood quality of saw timber can be degraded (Figure 1d) [4,6-9].

Pinus strobus is economically and ecologically important in New England. Pinus strobus comprises the greatest portion of the growing stock in Massachusetts (24\%) followed by New Hampshire (21\%) as well as $10 \%$ of Maine's growing stock [10]. Pinus strobus represents $60 \%$ and $30 \%$ of what sawmills produce in New Hampshire and Maine, respectively. Pinus strobus also provides unique habitat for wildlife that other large conifer species cannot duplicate [11]. The current $P$. strobus resource, however, is aging as regenerating stands are rare [10].

Reports of damage caused by C. pinea were common in the $1930 \mathrm{~s}$, when initial studies on the pathogen's epidemiology were conducted [4,12]. Since then, there has been very little progress towards understanding the epidemiology of this pathogen. Recently significant damage has been reported [6-8]. Damage by $C$. pinea has been associated with dense stands, suppressed trees, and poor sites. Very little quantitative data, however, exist about Caliciopsis canker distribution and site conditions associated with disease. The objective of this study, therefore, was to assess the extent and severity of Caliciopsis canker in the region of Eastern North America with the greatest concentration of $P$. strobus and to explore environmental conditions associated with disease to identify areas at risk of damage. To meet our 
objective a survey was conducted in Maine, New Hampshire, and Massachusetts to determine presence and symptoms of $C$. pinea in P. strobus stands.
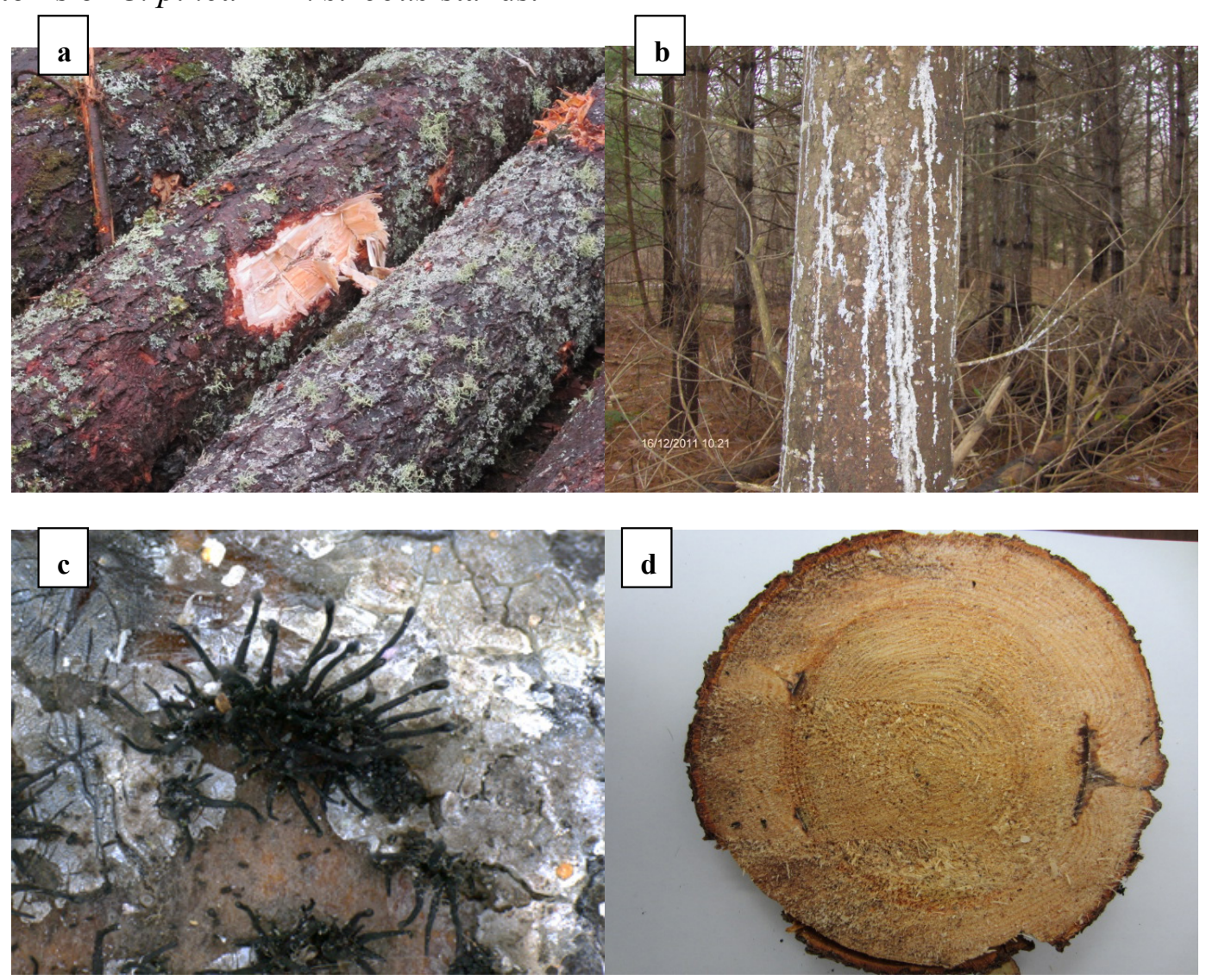

Figure 1. (a) Caliciopsis canker in the main stem of Pinus strobus; (b) Profuse pitching resulting from Caliciopsis canker; (c) Ascocarps of Caliciopsis pinea, each 1-3 mm in length; (d) saw timber damaged by $C$. pinea.

\section{Experimental Section}

\subsection{Study Area}

New England's climate is humid continental characterized by long, cold winters and moderately warm, short summers. Rainfall is spread throughout the year and most locations receive 1500-3000 mm of snowfall annually. New England soils developed from bedrock and surface deposits left behind by glaciers [13]. The study area encompasses three ecoregions defined by the Environmental Protection Agency (EPA) as: northeastern highlands, northeastern coastal zone, and Acadian plains and hills [14]. All three ecoregions have nutrient poor soils and dense concentrations of glacial lakes. The northeastern highlands are hilly, mountainous, and forested by northern hardwoods (Acer saccharum Marsh., Betula alleghaniensis Britton, Fagus grandifolia Ehrh.), spruce (Picea rubens Sarg., P. mariana (Mill.) Britton, Sterns and Poggenb., P. glauca (Moench) Voss) and fir (Abies balsamea (L.) Mill.). The northeastern coastal zone and Acadian plains and hills are less rugged than the northeastern highlands. The northeastern coastal zone is forested by oak (Quercus rubra L., Q. alba L., and Q. velutina Lam.) and oak-pine (same oaks mixed with P. strobus) and soils are Inceptisols and Entisols whereas the Acadian hills and plains are mostly forested by 
spruce-fir forest type with occasional mixed hardwoods and soils are predominantly frigid Spodosols. Both the northeastern highlands and northeastern coastal zones have been undergoing farm-to-forest conversion since the $1900 \mathrm{~s}$, but the northeastern coastal zone has a greater concentration of urban development. Pinus strobus is a common old-field colonizer, and hence ubiquitous in the region.

\subsection{Site Selection}

Two methods were applied to locate survey sites. A complete census of all 18 Forest Inventory and Analyses (FIA) plots with more than $75 \%$ basal area in P. strobus on public lands in Maine, Massachusetts, and New Hampshire were surveyed. FIA plots were established by the U.S. Forest Service to provide continuous forest census data in order to report status and trends in forest condition [15]. The second method applied to locate survey sites involved using the National Insect and Disease Risk Map (NIDRM) P. strobus host layer for use in GIS [16]. The NIDRM is a science-based, administrative tool created by forest health experts to determine the hazard to tree health posed by insects and diseases nationwide. The NIDRM uses GIS and a consistent modeling process that generates comparable results across geographic regions. In order to identify areas at risk of forest insects and diseases, first the distribution of host tree species must be determined and thus host tree layers for use in GIS were created [16]. For this project, sites with more than 2 contiguous hectares with more than $75 \%$ basal area of $P$. strobus as predicted by the NIDRM host layer on public lands were identified. Twenty of these sites were randomly selected for each State: New Hampshire and Maine. Latitude and longitude coordinates for the center point of each stand were generated and imported into a GPS receiver (GPSmap 64, Garmin International Inc., Olathe, KS, USA).

\subsection{Sampling}

In the field, a GPS receiver and compass were used to locate FIA plots or the center point of each stand selected using the NIDRM host layer. A 10 basal-area-factor prism was used at plot center to select sample trees $(>12.7 \mathrm{~cm}$ at diameter at breast height, $1.3 \mathrm{~m}$ from the ground). Trees per prism plot were converted to trees per hectare by calculating an expansion factor unique to each tree size. If Caliciopsis canker symptoms were observed on the way to plot center or at the prism plot, then four transects in each of the four cardinal directions (north, east, south, and west) were established. Data were collected for 25 P. strobus at least $3 \mathrm{~m}$ apart along each transect for a total of $100 \mathrm{P}$. strobus at each site. If insufficient pines were available in one of the cardinal directions, then more pines were surveyed in another of the cardinal directions to complete data for 100 pines per site. The following data were collected for each pine: dbh, crown class, live crown ratio, presence of $C$. pinea fruiting bodies, incidence and severity of Caliciopsis canker symptoms. Crown class is a category of tree based on its crown position relative to adjacent trees. For example, a dominant tree has a crown that extends above the general canopy whereas an intermediate tree has a crown that extends into the lower portion of the main canopy. The live crown ratio is the ratio of crown length to total tree height. Recent Caliciopsis canker infections are characterized by resin streaks throughout the bole of the tree (Figure 1b). Caliciopsis canker symptom severity was visually assessed by dividing the bole of the tree into thirds (bottom, middle, and upper stem) and counting the number of resin streaks in each section up to ten streaks per section. This assessment was conducted on two opposing faces of each tree and added for a maximum 
score of 60 resin streaks per tree. Resinosis associated with white pine blister rust symptoms, insect boring, decayed branch stubs, or mechanical damage was not considered in these assessments. The presence of $C$. pinea in understory $P$. strobus regeneration was recorded for each site. Caliciopsis fruiting bodies and infected plant tissue were collected from symptomatic pines or seedlings and identified based on morphological and molecular data to ensure signs and symptoms were in fact the result of $C$. pinea.

\subsection{Isolation and Identification of Caliciopsis pinea}

Pieces of infected tissue were examined for fruiting structures. A sterile scalpel was used to slice off a piece of the bark containing the fruiting structure, taking care to keep the relative shape and rigidity of the fruiting structure. Then forceps were used to place the bark piece onto the lid of an inverted petri dish, so the lid is on the bottom and potato dextrose agar (PDA) media on top, and then sealed with parafilm to induce sporulation. There was about $5 \mathrm{~mm}$ of distance between the tip of the fruiting structures and the agar. Plates were left for 2-3 days and examined for colony growth. Small colonies that were formed on the PDA were transferred onto fresh PDA plates. If colonies did not initially form after 3 days, a sterile needle with agar at the tip (from cooling the needle in agar) was used to gently touch the tips of the fruiting structures under a dissecting microscope and then plated out. Once pure cultures were established, isolates were transferred onto 2\% PDA plates overlaid with a cellophane membrane and grown for 1-2 weeks. Under aseptic conditions mycelium was scrapped off and placed inside $2 \mathrm{~mL}$ microcentrifuge tubes, frozen for 1 hour at $-80^{\circ} \mathrm{C}$, and freeze dried for two days. Genomic DNA extraction from dried mycelia followed the modified CTAB method from the 1000 fungal genome project [17]. Prior to this study there was no representative sequence of the internal transcribed spacer (ITS) regions 1 and 2, including the 5.8s rDNA for $C$. pinea. As the type specimen for $C$. pinea is no longer available we collected specimens from the host (P. strobus) and region (Northeastern U.S.) where the type specimen was originally collected [18]. Based on the morphological and ecological description of the type specimen we feel confident the isolates sequenced for this study represent $C$. pinea as described in the original investigation of the species as well as other early investigations on this fungus $[4,12]$. The ITS gene of six isolates of $C$. pinea were amplified using polymerase chain reaction and sequenced using primers ITS1F and ITS4 that amplify fungal DNA from the internal transcribed spacer (ITS) regions 1 and 2 according to methods developed previously for molecular identification of P. strobus pathogens [19], and were deposited in GenBank (Accession numbers still to come from GenBank). As there were no ITS sequences for $C$. pinea in GenBank, the ITS sequences for closely related species of Caliciopsis and Corynelia were imported from GenBank and included in a phylogenetic analysis to understand the relationship of $C$. pinea to other members of the Coryneliales. In addition, one isolate of $C$. pinea from $P$. strobus in West Virginia, U.S.A and two isolates of $C$. pinea recovered from $P$. nigra and $P$. radiata in Italy were included to compare our strains with those isolated in the southern U.S. and Europe. All sequences were imported into MEGA v.6.06 (http://www.megasoftware.net/faq.php), aligned using ClustalW and a phylogenetic tree developed using the Neighbor-joining and Maximum likelihood algorithms. 


\subsection{GIS Plot Data}

To explore the risk of damage by Caliciopsis canker in relation to environmental variables, we obtained data from publically available GIS layers that would be accessible by forest managers. These included: EPA ecological units [20], plant hardiness zones [21], soils [22], slope and aspect [23]. The plant hardiness zone map is based on mean annual winter temperature divided into $10^{\circ} \mathrm{F}$ zones and is employed by growers to determine which plants will succeed in a location. Soils were classified into important forest soil groups developed for New Hampshire [24].

\subsection{Statistical Analyses}

Fisher's exact test of independence was used to determine if the proportion of sites with Caliciopsis canker symptoms in overstory or understory P. strobus differed among nominal variables: EPA ecological units, plant hardiness zones, slope, or important forest soil group categories. To establish the effect of dbh, crown class, or soil type on incidence or presence of Caliciopsis canker symptoms, data were analyzed using a linear mixed model (PROC GLIMMIX) in SAS (SAS Institute Inc., version 9.4, 2012, Cary, NC, USA). "Dbh size class", "crown class", or "soil type" were fixed effects, "site" was a random factor and the response variable was "percentage of trees with Caliciopsis canker symptoms". Similarly, to establish the effect of tree and soil variables on Caliciopsis canker symptom severity or degree of damage, a linear mixed model (PROC GLIMMIX) was used. "Dbh size class", "crown class", or "soil type" were fixed effects, "site" was a random factor, and the negative binomial distribution with the log link function for the response variable "number of resin streaks per symptomatic tree" was applied [25]. When main effects were significant ( $\alpha=0.05)$, a Tukey-Kramer test was used to identify differences among means.

\section{Results and Discussion}

Caliciopsis canker symptoms were more widespread than expected (Figure 2). Caliciopsis canker symptoms were observed in $42(72 \%)$ of the 58 sites surveyed. Of these, 33 had sufficient pine and Caliciopsis canker symptoms to establish transects with 100 trees $(>12.7 \mathrm{~cm} \mathrm{dbh})$ per site. Thirty five percent of the 3258 trees in transects had Caliciopsis canker symptoms (ranged from 3 to 87 affected trees per site). According to FIA data, the area forested by $>75 \%$ P. strobus basal area in Maine, Massachusetts, and New Hampshire, is 145,232 hectares with a sampling error of 12.4\% (Randall Morin, U.S. Forest Service Northern Research Station's Forest Inventory and Analysis, personal communication). Of the 18 FIA plots surveyed, 14 (78\%) had Caliciopsis canker symptoms, suggesting that 112,958 hectares in these three states could potentially be affected by Caliciopsis canker. Caliciopsis pinea was found causing cankers and fruiting on $P$. strobus regeneration in 32 (55\%) sites. The fungus fruits readily in the branch axils of $P$. strobus saplings. Caliciopsis pinea fruiting bodies on infected woody tissues were collected from 27 sites with symptomatic pines or seedlings and used for morphological and molecular identification. 


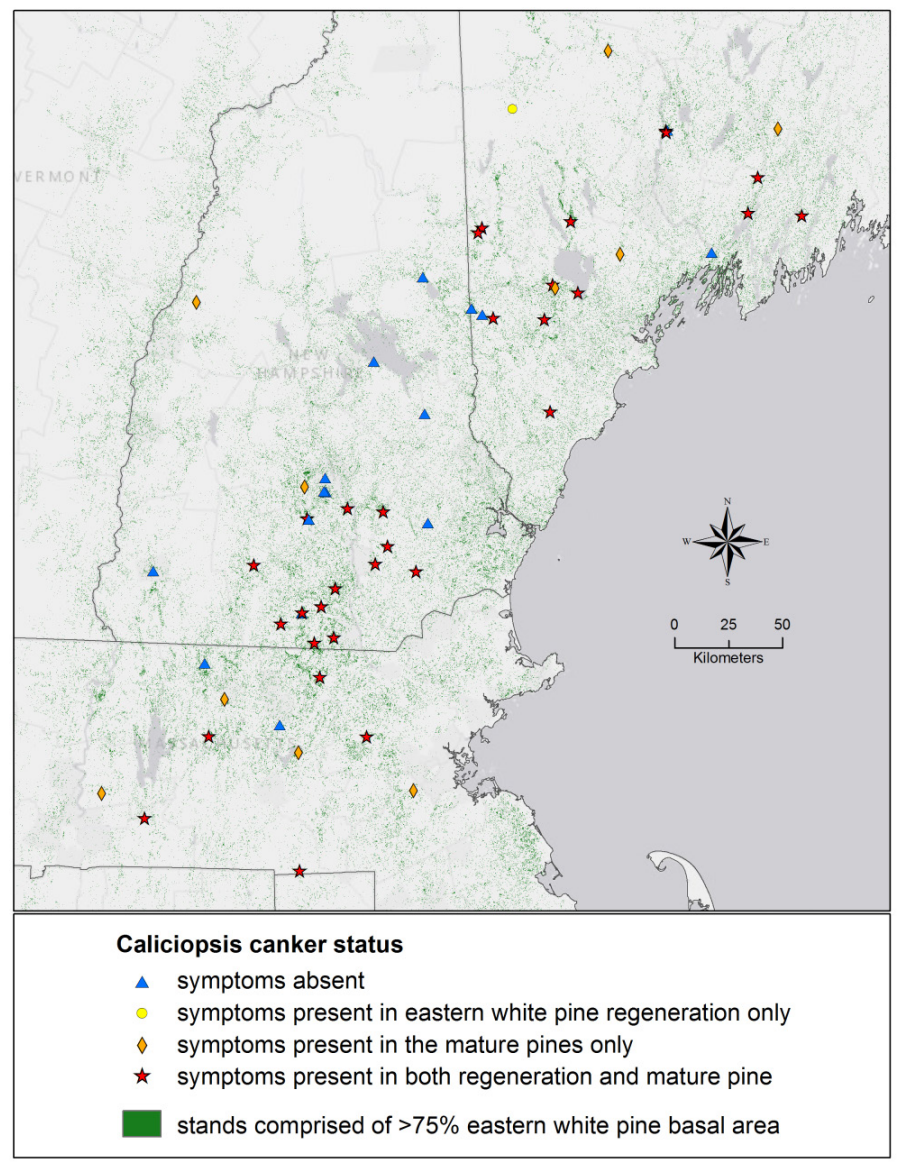

Figure 2. Location of 58 sites sampled in Maine, Massachusetts, and New Hampshire during 2014 and the presence of Caliciopsis canker symptoms at those locations.

Isolates of $C$. pinea were successfully cultured from ascospores ejected onto inverted PDA, as well as from infected wood tissue directly plated on PDA after surface sterilization. The six sequences deposited in GenBank represent the first ITS sequences of $C$. pinea, and as these isolates were recovered from $P$. strobus in the northeast, just as the type culture was, they should be considered the best available proxy of the type culture ITS sequence. This is also of importance for future phylogenetic studies of all Caliciopsis species as $C$. pinea is the type specimen for the genus Caliciospsis. In our phylogenetic analysis, all isolates of $C$. pinea from North America cluster together into a single group, and the two isolates from Italy cluster together in a second distinct group with strong bootstrap support (94\%) for this division (Figure 3). Preliminary analysis would indicate isolates from North America and Italy represent distinct species, but further analysis of other genes and additional isolates from Italy and Europe are needed to draw any definitive conclusions. The other species of Caliciopsis clustered together in a second group, and were more closely related to each other than to $C$. pinea (Figure 3). However, there is strong bootstrap support (95\%) for all the Caliciopsis species representing a single lineage, distinct from species of the closest known genus Corynelia. 


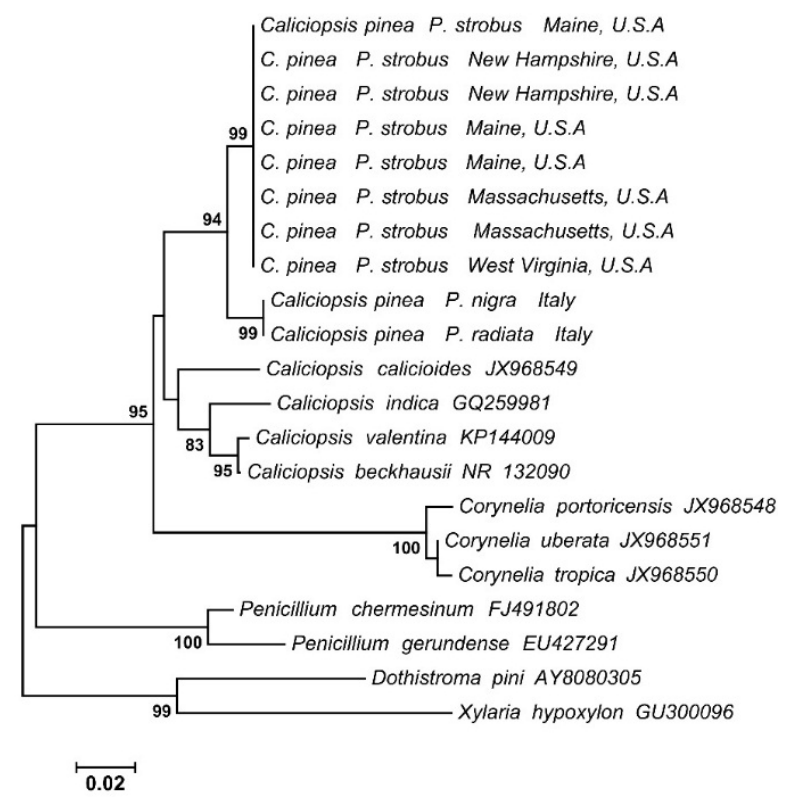

Figure 3. Neighbor-joining phylogenetic tree based on the ITS sequence of fungi isolated from Caliciopsis pinea fruiting bodies or infected plant tissue, as well as closely related species imported from Genbank or provided by collaborators. C. pinea isolates are followed by host species and location the isolate was recovered from. Remaining isolates are followed by their respective Genbank accession numbers. Bootstrap values $>70 \%$ were included at the nodes.

Using the NIDRM $P$. strobus host layer was an effective method to locate and randomly select $P$. strobus stands to survey. For example, 20 out of 29 sites visited in Maine were indeed $P$. strobus stands as predicted by NIDRM. Most sites surveyed were located in the northeastern coastal zone (32 sites), in the plant hardiness zone $5 \mathrm{~b}$ with mean annual extreme minimum temperature ranging from $-23^{\circ}$ to $-26{ }^{\circ} \mathrm{C}$ (30 sites) [21], and on flat slopes (mean slope $=5 \%$, range $=0 \%-20 \%$ ). The majority of these nominal variables did not have a significant effect on the proportion of sites with Caliciopsis canker across their categories. For example, for the three EPA ecoregions: northeastern highlands, northeastern coastal zone, and Acadian plains and hills, $p=0.46$ indicating that the proportion of sites with Caliciopsis canker symptoms was independent of ecoregion. Similarly, the proportion of sites with Caliciopsis canker was independent of plant hardiness zone three categories: $4 \mathrm{~b}-5 \mathrm{a}, 5 \mathrm{~b}$, and $6 \mathrm{a}-6 \mathrm{~b}(p=0.28)$ and for the three slope categories: $0,1 \%-9 \%$, and $10 \%-20 \%(p=0.9)$.

Important forest soil groups, however, were a more promising predictor of the probability of a site having Caliciopsis canker symptoms compared to EPA ecoregions, plant hardiness zones, and slope. The proportion of sites with Caliciopsis canker symptoms was greater for excessively drained or poorly drained soils (soil groups IC, IIB, and NC) compared to well-drained more fertile soils (IA, IB, and IIA) (Table 1) [24]. The proportion of sites with Caliciopsis canker symptoms was independent of forest soil group at $p=0.05$, but significant at $p=0.1$. The proportion of trees with Caliciopsis canker symptoms was constant (34\%-37\%) across New Hampshire important forest soil groups (Figure 4a). The severity of symptoms, however, varied among important forest soil groups $(p=0.027)$ and was greater for the IC with excessively drained, nutrient poor soils than for the IA-IB-IIA groups with well-drained, more nutrient rich soils (Figure 4b). Conceivably pines growing in better soils have more 
resources to grow and might be less susceptible to disease. If forest soils were indicative of Caliciopsis canker damage, it would be informative to foresters who are likely to use forest soils information to make management decisions [22].

Table 1. Proportion of sites with Caliciopsis canker symptoms across important forest soil groups.

\begin{tabular}{cccc}
\hline Soil Group & Description & $\begin{array}{c}\text { Percentage Sites } \\
\text { with Caliciopsis } \\
\text { Canker Symptoms }\end{array}$ & $\begin{array}{c}\text { No. } \\
\text { Sites }\end{array}$ \\
\hline IA-IB-IIA & $\begin{array}{c}\text { well drained, loamy, favourable moisture } \\
\text { conditions, fertility suitable for hardwoods } \\
\text { excessively drained, very dry, coarse textured } \\
\text { soils derived from glacial outwash, fertility } \\
\text { IC }\end{array}$ & 59 & 27 \\
adequate for softwoods but not hardwoods & 86 & 21 \\
\hline
\end{tabular}
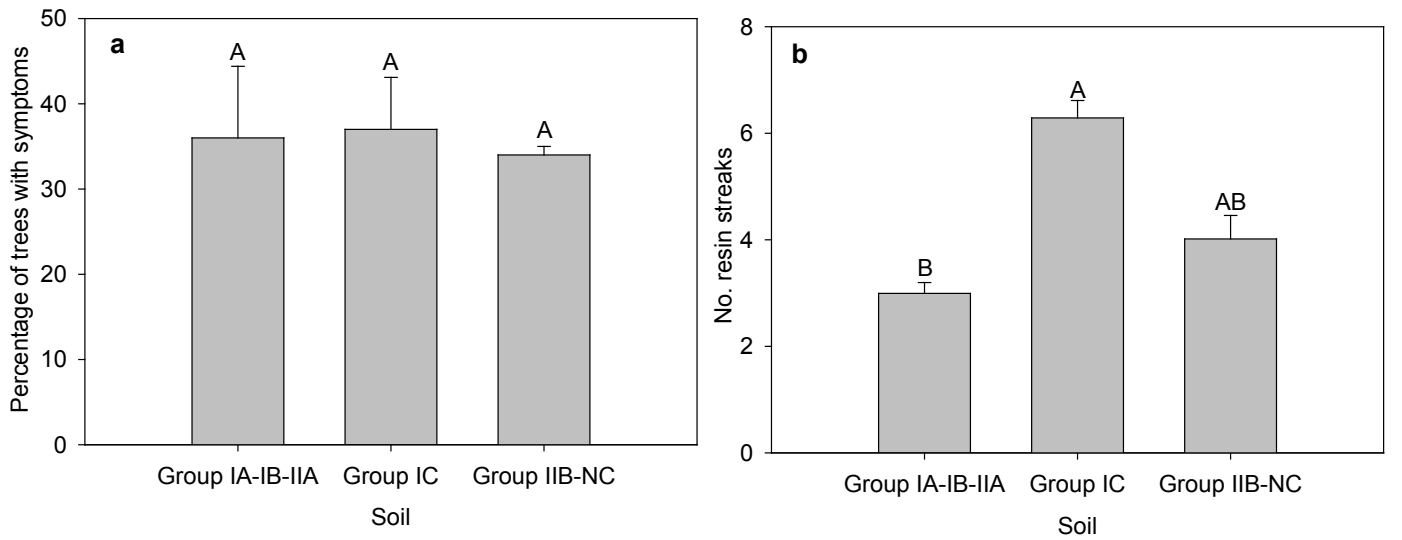

Figure 4. (a) Incidence; (b) and severity of Caliciopsis canker symptoms in relation to important forest soil groups. Bars represent means and standard errors. Values with the same letter are not statistically different $(\alpha=0.05)$.

Pinus strobus density was another promising predictive factor of the probability of a site having Caliciopsis canker symptoms. Pinus strobus density for sites with Caliciopsis canker was 311 trees/ha compared to 220 trees/ha for sites without Caliciopsis canker $(p=0.1)$. High stand density and shallow soils were associated with white pine decline in southern Maine where trees growing under these conditions were predisposed to drought as restricted rooting depth and competition from other trees resulted in less available water [26]. Other stress factors including heavy loss of needles from any of several recently-occurring needle diseases (Lophophacidium dooksii, Lecanosticta acicola, and Bifusella linearis), in addition to overstocking and drought may also facilitate infection by C. pinea. To further explore the relationship between Caliciopsis canker incidence, soil and P. strobus density studies are underway with more systematic sampling within each soil group and intensive stand density measurements at each site.

Tree size and crown class were good predictors of a tree having Caliciopsis canker symptoms. Pole size, suppressed, and intermediate trees were more likely to have Caliciopsis canker symptoms and more severe symptoms than sawtimber, codominant trees (Figures 5 and 6). Sawtimber sized trees were more 
frequent (2481) than poletimber sized trees (776). Similarly, trees with codominant crown positions (2516) were more frequent than suppressed and intermediate trees (589).
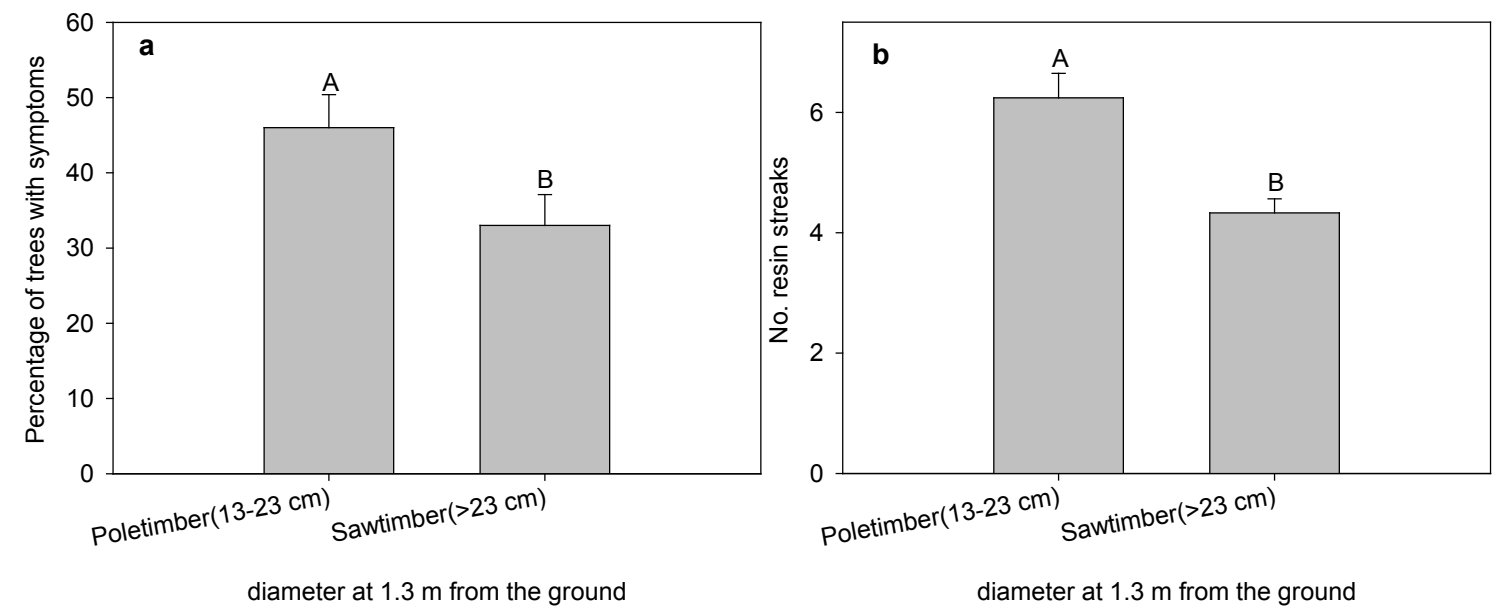

Figure 5. (a) Incidence; (b) and severity of Caliciopsis canker symptoms in relation to size class. Bars represent means and standard errors. Values with the same letter are not statistically different $(\alpha=0.05)$.
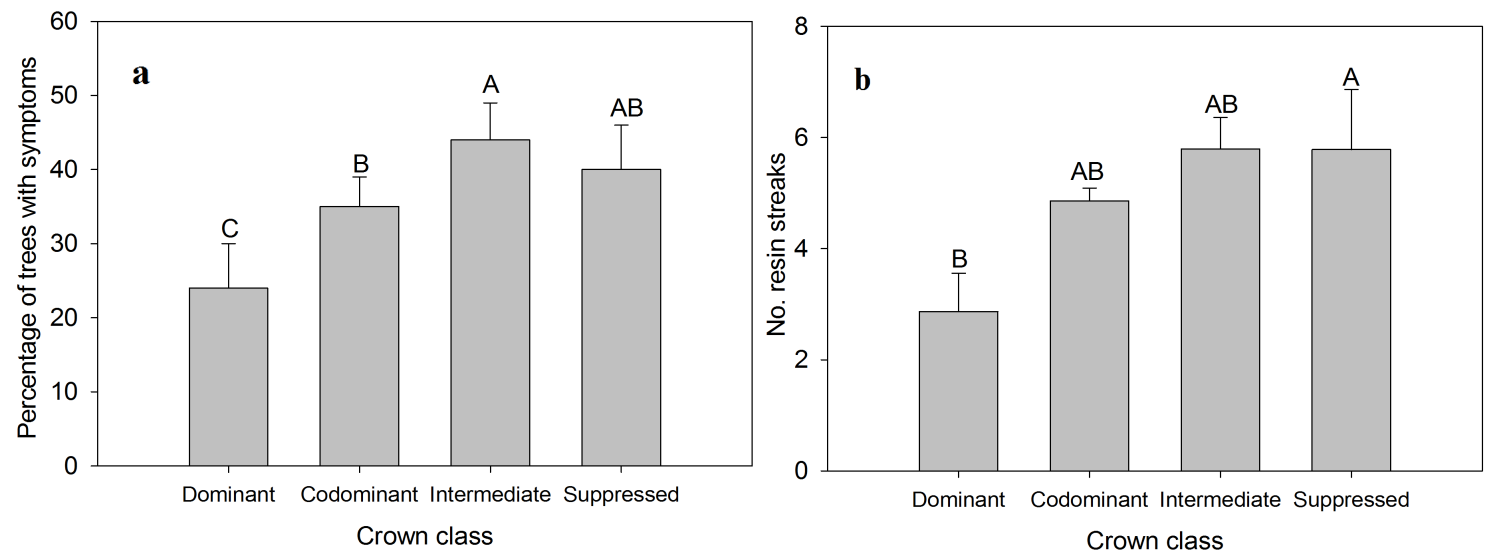

Figure 6. (a) Incidence; (b) and severity of Caliciopsis canker symptoms in relation to crown class. Bars represent means and standard errors. Values with the same letter are not statistically different $(\alpha=0.05)$.

Caliciopsis canker symptoms become increasingly difficult to diagnose with increasing tree size. Profuse pitching is indicative of recent infections and is relatively common in pole size trees with smooth bark. As trees increase in size and bark roughens, profuse pitching is less frequently encountered. Older cankers tend to be surrounded by blackened, rough, and sunken bark and may still have visible pitching, but it becomes more difficult to see as the resin darkens with time. Symptoms in affected stands, therefore, are more difficult to assess as trees grow from pole to timber size where trees without resinosis can exhibit internal damage. It is possible that we might have underestimated the number of affected trees as profuse pitching is a symptom of recent infections and trees with older, internal damage can lack external pitching. Alternatively, we might have overestimated the number of trees with Caliciopsis canker by relying on pitching as the main symptom associated with the disease, although we did exclude 
pitching associated with insects, mechanical damage, internal decay, and white pine blister rust. Given the difficulty of assessing internal damage caused by $C$. pinea from the ground, studies that include tree harvesting are underway to better quantify damage to the wood product and the reliability of pitching as a survey tool for this disease. Cankers of symptomatic trees are being assessed for the presence of C. pinea and other fungi.

Caliciopsis canker has been reported more frequently in the last decade [6,7]. Most P. strobus stands in New England are characterized by high stocking which is associated with $C$. pinea damage [27]. Alternatively, damage by might have been underreported in the past when management of P. strobus was dominated by the threat of white pine blister rust caused by the exotic pathogen Cronartium ribicola [28]. Symptoms of both diseases, such as resinosis, are similar and might have been misidentified. Management practices that favor white pine blister rust control might have favored Caliciopsis canker development. For example, high stand density was encouraged for white pine blister rust management to promote early branch pruning. Environmental conditions that precede Caliciopsis canker development are being investigated.

\section{Conclusions}

This is the first effort to quantify Caliciopsis canker damage in a region of Eastern North America with a high concentration of $P$. strobus. Caliciopsis pinea is causing cankers and damage in more sites than previously reported. Caliciopsis pinea was successfully isolated from fruiting bodies and ITS sequences from six isolates were deposited for the first time in GenBank, which will be important for future phylogenetic studies. The pathogen is widespread in New England where P. strobus is an important timber product. Canker damage degrades the lumber and C. pinea alone or in combination with other factors may lead to tree mortality. Pole-size trees or trees with poor growth exhibit more external symptoms than sawtimber and codominant trees. Regeneration is frequently infected by $C$. pinea and this poses a threat to the future forests given that the $P$. strobus resource is aging in New England. Soil and stand density might be associated with a greater frequency of Caliciopsis canker damage and these relationships merit further investigations. A better understanding of this pathogen is important for forest managers to better manage the $P$. strobus resource and increase the value of the lumber.

\section{Acknowledgments}

This work was funded by USDA Forest Service grants \# 14-DG-11420004-155, 14-DG-11420004-161, and 14-DG-1142004-229. The authors would like to thank Jake Mavrogeorge from the USFS STEP/Pathway Program, Maia Beh, and Wayne Searles for field assistance, Garret Dubois for C. pinea ascocarp photograph, Dr. Nicola Luchi for $C$. pinea sequence data for isolates from Italy and Michelle Cram from the USFS for the sequence data for the $C$. pinea isolates from West Virginia.

\section{Author Contributions}

Isabel A. Munck, William Livingston, Kyle Lombard, and William D. Ostrofsky conceived and designed the project and experiments. Thomas Luther collected and analyzed GIS data and created maps. 
William D. Ostrofsky, Jennifer Weimer, and Isabel A. Munck conducted field work. Stephen Wyka and Kirk Broders completed the fungal isolation, molecular identification and phylogenetic analysis and writing of this section. Isabel A. Munck analyzed field data and wrote the rest of the paper. William Livingston, Kyle Lombard, Thomas Luther, Jennifer Weimer, William D. Ostrofsky, and Kirk Broders reviewed drafts.

\section{Conflicts of Interest}

The authors declare no conflict of interest.

\section{References and Notes}

1. Farr, D.F.; Rossman, A.Y. Fungal Databases, Systematic Mycology and Microbiology Laboratory, ARS, USDA. Available online: http://nt.ars-grin.gov/fungaldatabases/ (accessed on 17 September 2015).

2. Luchi, N.; Capretti, P.; Migliorini, D.; Santini, A. Caliciopsis Canker: A Damaging Disease on Plantations in Italy. Abstracts of the Joint IUFRO 7.02.02 "Foliage, shoot and stem diseases of forest trees" and 7.03.04 "Diseases and insects in forest nurseries". In Proceedings of Working Parties Meeting, Uppsala, Sweden, 7-12 June 2015; Swedish University of Agricultural Sciences: Uppsala, Sweden, 2015; p. 21.

3. Funk, A. Studies in the genus Caliciopsis. Can. J. Bot. 1963, 41, 530-543.

4. Ray, W.W. Pathogenicity and cultural experiments with Caliciopsis pinea. Mycologia 1936, 28, 201-208.

5. Delatour, C. Caliciopsis pinea: Further results of artificial inoculations. Ann. Sci. for., Paris. 1969, 26, 285-295.

6. Lombard, K. Caliciopsis canker (pine canker) Caliciopsis pinea. In UNH Cooperative Extension Publication; UNH: Durham, NH, USA, 2003.

7. Asaro, C. What is killing white pine in the highlands of West Virginia? In Forest Health Review May 2011; Virginia Department of Forestry: Charlottesville, VA, USA, 2011.

8. Murphy, B. New Hampshire forest officials to study white pine canker. Wall Street Journal, 3 July 2012.

9. USDA Forest Service. 2000 Forest Health Highlights New Hampshire. Available online: http://www.fs.fed.us/foresthealth/fhm/fhh/fhh-00/nh/nh\%20_00.pdf (accessed on 16 November 2015).

10. Widmann, R.; McWilliams, W. An Overview of the White Pine Resource in New England Using Forest Inventory and Analyses Data. In Managing White Pine in a New Millennium; Bennett, K., Desmarais, K., Eds.; University of New Hampshire Cooperative Extention: Hillsborough, NH, USA, 2003; pp. 1-8.

11. Yamasaki, M. White Pine as Wildlife Habitat. In Managing White Pine in a New Millennium; Benett, K.; Desmarais, K., Eds.; University of New Hampshire Cooperative Extention: Hillsborough, NH, USA, 2003; pp. 33-36.

12. McCormack, H.W. The morphology and development of Caliciopsis pinea. Mycologia 1936, 28, 188-196. 
13. Sperduto, D.D.; Nichols, W.F. Natural Communities of New Hampshire; New Hampshire Natural Heritage Bureau: Concord, NH, USA, 2004.

14. Environmetal Protection Agency. Level III and IV Ecoregions of the Continental United States. Available online: http://www.epa.gov/wed/pages/ecoregions/level_iii_iv.htm (accessed on 16 September 2015).

15. Forest Inventory and Analysis National Program-USDA Forest Service. Available online: http://www.fia.fs.fed.us/ (accessed on 3 September 2015).

16. Krist, F.J.; Ellenwood, J.R.; Woods, M.E.; McMahan, A.J.; Cowardin, J.P.; Ryerson, D.E.; Sapio, F.; Zweifler, M.O.; Romero, S.A. 2013-2014 National Insect and Disease Forest Risk Assessment. Available online: http://www.fs.fed.us/foresthealth/technology/nidrm.shtml\#NIDRMReport (accessed on 16 June 2015).

17. Kohler, A.; Murat, C.; Costa, M. High Quality Genomic DNA Extraction Using CTAB and Qiagen genomic-tip. Version 2; INRA Nancy Equipe Ecogénomique UMR Iam; Available online: http://1000.fungalgenomes.org/home/wp-content/uploads/2013/02/genomicDNAProtocol-K0511.pdf (accessed on 16 November 2015).

18. Peck, C. Report of the Botanis. Ann. Rep. N.Y. State Mus. Nat. Hist. 1880, 33, 32.

19. Broders, K.D.; Munck, I.; Wyka, S.; Iriarte, G.; Beaudoin, E. Characterization of fungal pathogens associated with White Pine Needle Damage (WPND) in Northeastern North America. Forests 2015, 6, 4088-4104.

20. Griffith, G.E.; Omernik, J.M.; Bryce, S.A.; Royte, J.; Hoar, W.D.; Homer, J.W.; Keirstead, D.; Metzler, K.J.; Hellyer, G. Ecoregions of New England. Available online: http://www.epa.gov/ wed/pages/ecoregions/new_eng_eco.htm (accessed on 16 January 2015).

21. USDA Agriultural Research Service. USDA Plant Hardiness Zone Map. Available online: http://planthardiness.ars.usda.gov (accessed on 16 January 2015).

22. USDA Natural Resources Conservation Service. Soil Data Access. Available online: http://sdmdataaccess.nrcs.usda.gov/ (accessed on 16 January 2015).

23. US Geological Survey. Elevation. Available online: http://nationalmap.gov/elevation.html (accessed on 16 January 2015).

24. University of New Hampshire Cooperative Extension. Important Forest Soil Groups. Available online: https://extension.unh.edu/goodforestry/html/app-soils.htm (accessed on 16 January 2014).

25. O'Hara, R.B.; Kotze, D.J. Do not log-transform count data. Methods Ecol. Evol. 2010, 1, 118-122.

26. Fries, M.L. Relationships Between Rooting Restrictions, Radial Growth, and Drought Stress with White Pine (Pinus strobus) Decline in Southern Maine; The University of Maine: Orono, ME, USA, 2002.

27. Leak, W.B.; Cullen, J.B.; Frieswyk, T.S. Dynamics of White Pine in New England; Research Paper NE-699; USDA Forest Service, Northeastern Area State and Private Forestry: Radnor, PA, USA, 1995. 
28. Ostry, M.E.; Laflamme, G.; Katovich, S.A. Silvicultural approaches for management of eastern white pine to minimize impacts of damaging agents. For. Pathol. 2010, 40, 332-346.

(C) 2015 by the authors; licensee MDPI, Basel, Switzerland. This article is an open access article distributed under the terms and conditions of the Creative Commons Attribution license (http://creativecommons.org/licenses/by/4.0/). 